\title{
Evaluation of the Depression, Anxiety Levels and Attitudes of Mothers of Children with Celiac Disease
}

\section{Çölyak Hastalığı Olan Çocukların Annelerinin Depresyon, Kaygı Düzeyleri ve Tutumlarının Değerlendirilmesi}

\author{
Guzide Dogan ${ }^{1 \oplus}$, Sermin Yalin Sapmaz ${ }^{2 \oplus}$, Yeliz Cagan Appak $^{1 \oplus}$, Masum Ozturk $^{2 \oplus}$, Yesim Yigit $^{3} \odot$ \\ Erhun Kasirga ${ }^{1 \oplus}$ \\ ${ }^{1}$ Celal Bayar University Faculty of Medicine, Department of Pediatric Gastroenterology, Hepatology and Nutrition, Manisa, Turkey \\ ${ }^{2}$ Celal Bayar University Faculty of Medicine Department of Child psychiatry, Manisa, Turkey \\ ${ }^{3}$ Celal Bayar University Faculty of Medicine, Department of Pediatrics, Manisa, Turkey
}

Received: 17.06.2020 / Accepted: 01.09.2020 / Published Online: 29.09.2020

Cite as: Dogan G, Yalın Sapmaz S, Çagan Appak Y, Ozturk M, Yigit Y, Kasirga E. Evaluation of the depression, anxiety levels and attitudes of mothers of children with celiac disease. Med J Bakirkoy 2020;16(4):369-73.

\section{ABSTRACT}

Objective: In celiac disease, a gluten-free diet is required for lifelong. Difficulties experienced by children with celiac disease can also negatively affect caregivers. The aim of this study is to evaluate the anxiety and depression of mothers having a child with celiac disease, and evaluate mothers' attitude towards their children.

Method: Thirty-six children with celiac disease, their mothers, and 36 healthy controls were included in the study. The Parent Attitude Research Instrument, State-Trait Anxiety Inventory, and the Beck Depression Inventory were completed by all mothers.

Results: The mothers of children with celiac disease had significantly higher scores in depression and state-trait anxiety than the mothers of the healthy children. Mothers of children with celiac disease had significantly higher scores in the attitude of overparenting, authoritarian attitude and attitude of hostility and rejection than the mothers of healthy children.

Conclusion: This study revealed that having a child with celiac disease might have negative effects on mothers and their attitudes towards their children. Because of psychopathologic risks appropriate psychologic support should be provided for mothers.

Keywords: Çölyak hastalığı, çocuklar, annelerin tutumu, psikolojik durum

öz

Amaç: Çölyak hastalığında ömür boyu glutensiz diyet gerekmektedir. Çölyak hastalığı olan çocukların yaşadığı zorluklar, bakım veren kişileri de olumsuz etkileyebilir. Bu çalışmanın amacı, çölyak hastası çocuğu olan annelerin kaygı ve depresyonunu değerlendirmek ve annelerin çocuklarına karşı tutumunu değerlendirmektir.

Yöntem: Otuzaltı çölyak hastası çocuk ve annesi ile 36 sağlıklı çocuk ve annesi çalışmaya dahil edildi. Aile hayatı ve çocuk yetiştirme tutumları ölçeği, durumluk sürekli kaygı envanteri ve Beck Depresyon envanteri tüm anneler tarafından dolduruldu.

Bulgular: Çölyak hastası çocukların annelerinin, depresyon ve kaygı düzeyleri, sağlıklı çocukların annelerine göre anlamlı yüksek saptandı. Aile hayatı çocuk yetiştirme tutum ölçeğinde, aşırı annelik, gereken ilgiyi gösterme, baskı ve disiplin alt boyutlarında, sağlıkı çocukların annelerine göre anlamlı oranda yüksek puan bulundu.

Sonuç: Bu çalışma çölyak hastalığının çölyaklı çocukların annelerinin yaşamları ve çocuklarına karşı tutumlarını olumsuz yönde etkileyebileceğini gösterdi. Çölyak hastalığı olan çocukların annelerinde psikopatolojik risk görülebileceğinden, annelere uygun psikososyal destek verilmelidir.

Anahtar kelimeler: Celiac disease, children, mothers' attitude, psychological state

Corresponding Author:

guzidedogan@gmail.com
G. Dogan 0000-0003-4291-7282

S. Yalin Sapmaz 0000-0002-1084-5053

Y. Cagan Appak 0000-0002-4330-9281
M. Ozturk 0000-0002-9989-7051

Y. Yigit 0000-0002-0255-1266

E. Kasirga 0000-0002-8113-286X

(C) Telif hakkı Sağlık Bilimleri Üniversitesi Bakırköy Dr. Sadi Konuk Eğitim ve Araştırma Hastanesi'ne aittir. Logos Tıp Yayıncılık tarafından yayınlanmaktadır. Bu dergide yayınlanan bütün makaleler Creative Commons Atff-GayriTicari 4.0 Uluslararası Lisansı ile lisanslanmıştır.

C Copyright Health Sciences University Bakırköy Sadi Konuk Training and Research Hospital. This journal published by Logos Medical Publishing.

Licenced by Creative Commons Attribution-NonCommercial 4.0 International (CC BY) 


\section{INTRODUCTION}

Celiac disease (CD) is a chronic disease caused by immunologic and environmental factors, primarily affecting small intestines and is usually observed in genetically sensitive people ${ }^{(1,2)}$. Abdominal pain-distention, diarrhea, vomiting, failure to thrive and constipation can be noticed in childhood, while short stature, puberty latency, aphthous stomatitis, refractory iron deficiency anemia, osteoporosis and dyspeptic complaints can appear during childhood and adolescence. Nowadays, the only treatment for celiac disease is a lifelong gluten-free diet ${ }^{(3,4)}$.

During the course of chronic disease and the treatment process, both the children and their parents encounter many short- and long-term troubles ${ }^{(5-7)}$. Parents who have children with chronic illnesses may also more frequently develop mental problems. Taking care of a child with a chronic illness requires more effort when compared to taking care of a healthy child ${ }^{(8-10)}$. Overall, the literature suggests that the adaption to illness following diagnosis seems to be related to personal and familial characteristics ${ }^{(11,12)}$.

There isn't sufficient data in the literature specifically examining maternal experiences of childhood celiac disease. The aim of the present study is to investigate how having a child with $C D$ affects the anxiety, depression levels, and attitudes of mothers.

\section{MATERIAL and METHODS}

\section{Study Population:}

Children between the ages of 4-18, who were diagnosed with celiac disease (CD) according to the European Society for Paediatric Gastroenterology Hepatology and Nutrition diagnosis criteria ${ }^{(2)}$, and their mothers were included in the study. Children with some other chronic disease and/or CD diagnosis with less than six months were excluded from the study.

Study participants were evaluated in detail with regard to the duration of gluten-free diet (GFD), compliance to the GFD and the factors that affect the compliance to the GFD. GFD compliance was evaluated according to the patients' and the mothers' verbal responses.
After the participants in the CD group were selected, a control group was formed. The healthy children with similar demographic features and their mothers were enrolled. They were selected randomly from the general pediatric outpatient clinic. The children and their mothers without any chronic complaints, chronic disease and psychiatric diagnosis were included in the control group. The sociodemographic data of mothers and children were recorded. Written informed consent was obtained from all mothers and their children who agreed to participate in the study.

This study was conducted in conformity to the Helsinki Declaration and approved by our local research ethics committee (04/08/2015; 20478486-184).

\section{Child and Family Assessment Tools}

\section{Beck Depression Inventory (BDI):}

The BDI measures physical, emotional, and cognitive symptoms noted during depression. In this study, this survey was completed by mothers and aimed to rate depressive symptoms in these respondents. Developed by Beck and colleagues in $1961^{(13)}$ this scale is a self-asessment inventory covering $21 \mathrm{symp}$ tom categories. The scores for each item vary from zero to three points. High total scores indicate a greater severity of depression. The validity and reliability study for this scale in Turkey was undertaken by Hisli ${ }^{(14)}$.

\section{State-Trait Anxiety Inventory (STAI):}

The STAI is typically used to investigate anxiety levels. In this study, it was completed by mothers and aimed to understand anxiety symptoms in these individuals. Developed by Spielberger and colleagues in $1970{ }^{(15)}$, the state anxiety scale measures how a person feels under certain conditions, at a certain point of time; while the trait anxiety scale evaluates how a person feels independently of the state and conditions they are in. The scores for each item vary from one point (not at all) to four points (very much). Higher scores indicate a higher level of anxiety, while lower points indicate a lower level of anxiety. The inventory was translated into Turkish and adapted in 1977 by Oner ${ }^{(14)}$.

Parental Attitude Research Instrument (PARI): To evaluate parental attitudes towards child-rearing, 
the PARI scale was used. It was completed by mothers in the present study and sought to rate the child rearing attitudes of parents. The scale was developed in 1958 by Schaefer and Bell ${ }^{(16)}$ and includes 60 items and five subscales. The answers given by mothers are stratified as follows: overprotective mother, democratic attitude, recognition of equality, rejecting the role of being a housewife, marital conflict and incompatibility, and strict discipline and pressure. It is a four-point Likert-type scale. All items are rated with a directly scored grade, except for items 2, 29, and 44. For each factor dimension, the scores are summed separately. An increase in points for all categories except "democratic attitude" indicates the presence of negative parental attitudes. The scale was adapted by Oner to Turkish in $1978^{(14)}$.

\section{Statistical Analysis:}

In this research, numeric variables were presented as means \pm standard deviations and categorical variables were presented as numbers and percentages. The distribution of the data was evaluated using the Kolmogorov-Smirnov method. Since the data demonstrated normal distribution, the chi-square test was used for categorical data, and a t-test for parametric data. Pearson correlation analysis was used to determine the relationships between continuous variables. A bidirectional hypothesis was established for the research and the results were evaluated within $95 \%$ confidence intervals, level of significance was established as $p<0.05$.

A sample size of 33 participants (per group) was determined to be necessary, based on a power of $80 \%$ and an effect size $(d)=0.70$ of $\alpha^{2}=0.05$.
Table 1. Socio-demographic features of study group.

\begin{tabular}{|c|c|c|c|}
\hline & $\begin{array}{c}\text { Celiac } \\
\text { group } \\
\text { n (\%) }\end{array}$ & $\begin{array}{l}\text { Healthy } \\
\text { group } \\
\text { n (\%) }\end{array}$ & $\mathbf{P}$ \\
\hline \multicolumn{4}{|l|}{ Gender } \\
\hline Female & $13(36)$ & $11(30)$ & 0.694 \\
\hline $\begin{array}{l}\text { Employment status of the mothers } \\
\text { Housewife }\end{array}$ & $23(64)$ & $25(70)$ & \\
\hline Worker & $23(64)$ & $15(42)$ & 0.059 \\
\hline $\begin{array}{l}\text { Family structure } \\
\text { Extended family }\end{array}$ & $13(36)$ & $21(58)$ & \\
\hline Nuclear family & $\begin{array}{l}7(19.4) \\
29(80.6)\end{array}$ & $\begin{array}{l}4(11.1) \\
32(88.9)\end{array}$ & 0.326 \\
\hline
\end{tabular}

\section{RESULTS}

Thirty-six children with $C D$ with a mean age of $12.0 \pm 3.6$ years and 36 healthy children with a mean age of $11.6 \pm 3.4$ years were recruited for this study $(p=0.617)$. Five children with $C D$ diagnosis with less than six months were not included. Sociodemographic features of the study group are shown Table 1. Twenty-one (58.3\%) children with CD were accepted as non- adherent to GFD. The factors that may contribute to a difficulty in staying on a GFD were found to be unavailability of gluten-free foods at schools and restaurants (83.3\%), difficulty in finding a variety of gluten-free foods for sale (61.1\%), the bad taste of gluten-free foods (19.4\%), lack of information on packages about gluten (47.2\%), and giving up following the diet due to having no complaints and/or feeling healthy (27.8\%).

The results of the BDI, STAI, and PARI surveys are shown in Table 2. The total scores of BDI and STAI scores indicating mothers' psychological symptoms were found to be statistically significantly higher in mothers of children with $C D$ versus those in the control group, suggesting that mental complaints are more common in mothers of children with CD.

Table 2. Scores of Beck Depression Inventory, State and Trait Anxiety Inventory and Parental Attitude Research Instrument filled by mothers in the groups.

\begin{tabular}{|c|c|c|c|}
\hline & $\begin{array}{c}\text { Celiac group } \\
\text { Mean } \pm S D\end{array}$ & $\begin{array}{l}\text { Healthy group } \\
\text { Mean } \pm S D\end{array}$ & $\mathbf{P}^{*}$ \\
\hline Beck depression inventory & $9.79 \pm 8.56$ & $4.74 \pm 6.18$ & 0.007 \\
\hline State anxiety inventory & $39.11 \pm 9.90$ & $33.85 \pm 9.17$ & 0.025 \\
\hline Trait anxiety inventory & $43.84 \pm 9.68$ & $38.54 \pm 8.24$ & 0.018 \\
\hline \multicolumn{4}{|l|}{ Parental attitude research instrument } \\
\hline Attitude of over-parenting & $46.00 \pm 7.65$ & $35.57 \pm 9.50$ & 0.0001 \\
\hline Democratic attitudes & $27.37 \pm 4.15$ & $28.42 \pm 3.44$ & 0.251 \\
\hline Attitude of hostility and rejection & $31.57 \pm 8.25$ & $27.60 \pm 7.30$ & 0.037 \\
\hline Marital discordance & $14.40 \pm 4.20$ & $12.85 \pm 3.85$ & 0.115 \\
\hline Authoritarian attitude & $36.48 \pm 7.19$ & $26.71 \pm 7.51$ & 0.0001 \\
\hline
\end{tabular}

${ }^{*} t$ test was applied. $C D$ = celiac disease; $S D=$ standard deviation. 
Regarding mean scores obtained in PARI survey a statistically significant intergroup difference was observed for excessive motherhood, rejecting the role of being a housewife, and strict discipline,

The relationships between BDI, STAI, and PARI scores and the duration of illness were assessed without any significant correlation.

There was no significant difference regarding the BDI, STAI and PARI scores between patients who were and were not compliant with a GFD.

\section{DISCUSSION}

This study indicates that when it comes to maternal psychological well-being and mother's attitudes towards their own children, there were significant differences between the mothers of children with $C D$ and mothers of healthy children. We found that the mothers of children with $C D$ had significantly higher levels of depression, anxiety, excessive motherhood, rejecting the role of being a housewife, and strict discipline according to their mean scores.

Both children with chronic disease and their parents encounter many troubles besides the onset of such a disease and the process of treatment. A child's chronic illness may also influence parents' psychological adjustment. Many factors are likely to affect this situation such as the symptoms of the disease, frequent doctor visits, treatment processes, socioeconomic problems, adaptation to a certain diet, and inability to find an appropriate food for the diet. These reasons can cause distinction between studies. The study conducted in Turkey revealed no significant difference regarding anxiety and depression levels ${ }^{(17)}$. Another study conducted in Italy, parents of children with CD had higher parental stress than parents of healthy children ${ }^{(18)}$. In a study of children with $C D$ and their parents, parents expressed different views and difficulties concerning the symptoms of the disease, the process of getting a diagnosis, regarding regulating the diet, difficulties experienced at school and the social environment regarding the diet, the supply of food appropriate for the diet, economic concerns and the difficulties might be faced in the future ${ }^{(19)}$. Another study reports that the parents of children with CD who complied with a prescribed diet had less concerns regarding the health of their children but higher concerns about the negative effects that the disease may have on the future of their children ${ }^{(20)}$. Previous studies showed that the well-being of the child is influenced by the psychosocial problems of their parents (21). Parental psychosocial problems may have an effect on the physical health of the child with a chronic illness, in addition to influencing the psychosocial functioning of the child. Bartlett et al. have shown that the child's adherence to therapy is influenced by maternal depression ${ }^{(22)}$. Therefore, the mental assessment of parents is important.

Numerous studies have identified the importance of parenting behaviors to the well-being of children with chronic physical conditions ${ }^{(23)}$. The frequent observation of anxiety and depression symptoms in mothers may affect family functions and attitudes towards children. We found that mothers of children with $C D$ had more problems in the subscale of the overparenting, attitude of hostility and rejection, and strict discipline categories of the PARI. Overparenting involves issues such as extreme control, intervention, asking the child to be dependent, the mother being extremely self-sacrificing and believing that the child should also acknowledge that. The mother showing an attitude of hostility and rejection is tense, worried, and angry. Oppression and discipline involves acts such as forcing certain rules on the child and believing in the absolute domination of the parents ${ }^{(24)}$. Studies have suggested that parents of children with chronic illnesses are overprotective, have less close and positive relations with their children, and that the severity of the chronic illness leads to more frequent protecting and controlling behaviors in the parents ${ }^{(25-27)}$. The more efficient parenthood helps to decrease behavioral problems of children. Behavioral adaptations increase in frequency when the child's and the family's quality of life rises and the worries of parents lessen ${ }^{(11)}$.

Our study has some limitations that need to be acknowledged. The accuracy of our findings may not be reflected by the small sample size. Larger-scale studies comparing different chronic diseases (diabetes mellitus type 1) are needed to strengthen and increase meaningfulness of the study. This study included mothers without known psychiatric illness. However, the fact that the psychiatric evaluations of the mothers were not known in the period before children were diagnosed with CD was another limitation of the study. Additionally, data collection from other countries may help to identify whether any cultural differences affect childrens' behaviours, adherence rate for the GFD, contrubuting factors to maintain the GFD, and parental attitudes. 


\section{Conclusion}

The mothers have a major influence on the wellbeing and adjustment of their children, and play an important role in adaptation of their child to living with an illness. In the literature, there is a gap specifically when it comes to examining maternal attitudes towards children with CD. Thus, the results of our study is precious for the literature. In addition, determining psychological conditions such as anxiety and depression in the mothers of children with $C D$ who require special diet and care is important for the management of the disease. Consequently the children with $C D$ and their mothers should be provided with psychological assessment and support during diagnosis and follow-up.

Ethics Committee Approval: Celal Bayar University Clinical Research Ethics Committee approval was received (08/04/2015; 20478486-184).

Conflict of Interest: No conflict of interest was declared by the authors.

Funding: No funding was used for this study. Informed Consent: Informed consent was obtained from all mothers and their children.

\section{REFERENCES}

1. Benelli E, Zin A, Martelossi S. Celiac disease in children. Minerva Pediatr. 2019;71(1):39-46. https://doi.org/10.23736/S0026-4946.18.05366-5

2. Husby S, Koletzko S, Korponay-Szabó I, et al. European Society Paediatric Gastroenterology, Hepatology and Nutrition Guidelines for Diagnosing Coeliac Disease 2020. J Pediatr Gastroenterol Nutr. 2020;70(1):141-56. https://doi.org/10.1097/MPG.0000000000002497

3. Glissen Brown JR, Singh P. Coeliac disease. Paediatr Int Child Health. 2019;39(1):23-31. https://doi.org/10.1080/20469047.2018.1504431

4. Fasano A. Clinical presentation of celiac disease in the pediatric population. Gastroenterology. 2005;128(4Suppl1):68-73. https://doi.org/10.1053/j.gastro.2005.02.015

5. LeBlanc LA, Goldsmith T, Patel DR. Behavioral aspects of chronic illness in children and adolescents. Pediatr Clin North Am. 2003;50(4):859-78. https://doi.org/10.1016/S0031-3955(03)00072-5

6. Butwicka A, Lichtenstein P, Frisén L, et al. Celiac Disease Is Associated with Childhood Psychiatric Disorders: A PopulationBased Study. J Pediatr. 2017;184:87-93.e1.

https://doi.org/10.1016/j.jpeds.2017.01.043

7. Balázs J, Miklósi M, Keresztény $A$, et al. Comorbidity of Physical and Anxiety Symptoms in Adolescent: Functional Impairment, Self-Rated Health and Subjective Well-Being. Int J Environ Res Public Health. 2018;15(8):1698. https://doi.org/10.3390/ijerph15081698

8. Grootenhuis MA, Bronner MB. Paediatric illness! Family matters. Acta Paediatr. 2009;98(6):940-1. https://doi.org/10.1111/j.1651-2227.2009.01321.x

9. Van Oers HA, Haverman L, Limperg PF, et al. Anxiety and depression in mothers and fathers of a chronically ill child. Matern Child Health J. 2014;18(8):1993-2002. https://doi.org/10.1007/s10995-014-1445-8

10. Pinquart M. Parenting stress in caregivers of children with chronic physical condition-A meta-analysis. Stress Health. 2018;34(2):197-207.

https://doi.org/10.1002/smi.2780

11. Morawska A, Calam R, Fraser J. Parenting interventions for childhood chronic illness: a review and recommendations for intervention design and delivery. J Child Health Care. 2015;19(1):5-17.

https://doi.org/10.1177/1367493513496664

12. Crandell JL, Sandelowski M, Leeman J, et al. Parenting behaviors and the well-being of children with a chronic physical condition. Fam Syst Health. 2018;36(1):45-61. https://doi.org/10.1037/fsh0000305

13. Beck AT, Ward CH, Mendelson M, et al. An inventory for measuring depression. Arch Gen Psychiatry. 1961;4:561-71. https://doi.org/10.1001/archpsyc.1961.01710120031004

14. Öner N. Türkiye'de kullanilan psikolojik testler bir başvuru kaynaği [Psychological tests used in Turkey: A reference source]. 3rd ed. Istanbul: Boğaziçi Üniversitesi Yayınları; 1997. ISBN: 9755180443.

15. Spielberger CD, Gorsuch RL, Lushene RE. STAI manual for the state-trait anxiety inventory. Palo Alto, CA: Consulting Psychologists Press; 1970.

16. Schaefer ES, Bell RQ. Development of a parental attitude research instrument. Child Dev. 1958;29(3):339-61. https://doi.org/10.1111/j.1467-8624.1958.tb04891.x

17. Esenyel $S$, Unal F, Vural P. Depression and anxiety in child and adolescents with follow-up celiac disease and in their families. Turk J Gastroenterol. 2014;25(4):381-5. https://doi.org/10.5152/tjg.2014.4831

18. Epifanio MS, Genna V, Vitello MG, et al. Parenting stress and impact of illness in parents of children with coeliac disease. Pediatr Rep. 2013;5(4):e19. https://doi.org/10.4081/pr.2013.e19

19. Cederborg AC, Hultman E, Magnusson KF. Living with children who have coeliac disease: a parental perspective. Child Care Health Dev. 2012;38(4):484-9.

https://doi.org/10.1111/j.1365-2214.2011.01273.x

20. Anson O, Weizman Z, Zeevi N. Celiac disease: parental knowledge and attitudes of dietary compliance. Pediatrics. 1990;85(1):98-103. PMID: 2296499.

21. Wallander JL, Varni JW. Effects of pediatric chronic physical disorders on child and family adjustment. J Child Psychol Psychiatry. 1998;39(1):29-46. PMID: 9534085. https://doi.org/10.1017/S0021963097001741

22. Bartlett SJ, Krishnan JA, Riekert KA, et al. Maternal depressive symptoms and adherence to therapy in inner-city children with asthma. Pediatrics, 2004;113(2):229-37. https://doi.org/10.1542/peds.113.2.229

23. Crandell JL, Sandelowski M, Leeman J, et al. Parenting behaviors and the well-being of children with a chronic physical condition. Fam Syst Health. 2018;36(1):45-61. https://doi.org/10.1037/fsh0000305

24. Küçük Ş. The validity of the Turkish form of the PARI subscales II, III, IV [thesis]. Istanbul: Bogazici University, Graduate School of Social Sciences; 1987.

25. Pinquart M. Do the parent-child relationship and parenting behaviors differ between families with a child with and without chronic illness? A meta-analysis. Pediatr Psychol. 2013;38(7):708-21.

https://doi.org/10.1093/jpepsy/jst020

26. Holmbeck GN, Johnson SZ, Wills KE, et al. Observed and perceived parental overprotection in relation to psychosocial adjustment in preadolescents with a physical disability: the mediational role of behavioral autonomy. J Consult Clin Psychol. 2002;70(1):96-110. https://doi.org/10.1037/0022-006X.70.1.96

27. Power TG, Dahlquist LM, Thompson SM, et al. Interactions between children with juvenile rheumatoid arthritis and their mothers. J Pediatr Psychol. 2003;28(3):213-21. https://doi.org/10.1093/jpepsy/jsg009 